\title{
MRI-Guided and CT-Guided Cervical Nerve Root Infiltration Therapy: A Cost Comparison
}

\section{Kostenvergleich der MRT- und CT-gesteuerten periradikulären Schmerztherapie an der Halswirbelsäule}

\author{
Authors \\ M. H. Maurer ${ }^{1}$, V. Froeling ${ }^{1}$, R. Röttgen ${ }^{1}$, T. Bretschneider ${ }^{2}$, T. Hartwig ${ }^{3}$, A. C. Disch ${ }^{3}$, M. de Bucourt ${ }^{1}$, B. Hamm ${ }^{1}$, \\ F. Streitparth ${ }^{1}$ \\ Affiliations \\ Department of Diagnostic and Interventional Radiology, Charité University Medicine Berlin \\ Department of Radiology and Nuclear Medicine, Otto von Guericke University Magdeburg \\ Center for Musculoskeletal Surgery, Charité University Medicine Berlin
}

\author{
Key words \\ nerve root infiltration \\ - MRI fluoroscopy \\ CT fluoroscopy \\ - cost analysis \\ health economics
}

received $\quad 18.12 .2012$

accepted $\quad 21.10 .2013$

\section{Bibliography}

Dol http://dx.doi.org/

10.1055/s-0033-1356169

Published online: 17.12.2013

Fortschr Röntgenstr 2014; 186:

559-566 @ Georg Thieme

Verlag KG Stuttgart · New York ISSN 1438-9029

\section{Correspondence}

\section{Dr. Martin H. Maurer}

Klinik für diagnostische und interventionelle Radiologie, Charité - Universitätsmedizin Berlin Charité Campus Virchow-Klinikum, Augustenburger Platz 1 13353 Berlin Germany

Tel.: ++49/3 04/50657177 Fax: ++49/3 04/50557901 martin.maurer@charite.de

\section{Zusammenfassung \\ $\nabla$}

Ziel: Ein Vergleich der Kosten periradikulärer Nervenwurzelinfiltrationen an der Halswirbelsäule unter Computertomografie (CT)- und alternativ Magnetresonanztomografie (MRT)- Therapiesteuerung. Material und Methoden: In einem Zeitraum von September 2009 bis April 2012 erhielten 22 Patienten (9 Männer, 13 Frauen; Durchschnittsalter 48,2 Jahre) eine MRT-gesteuerte (1,0 Tesla, Panorama HFO, Philips) monosegmental-unilaterale periradikuläre Nervenwurzelinfiltration an der Halswirbelsäule mit $40 \mathrm{mg}$ Triamcinolonacetonid. Im gleichen Zeitraum wurden weitere 64 Patienten (34 Männer, 30 Frauen; Durchschnittsalter 50,3 Jahre) unter CT-fluoroskopischer Steuerung (Somatom Definition 64, Siemens) in gleicher Weise behandelt. Die Gesamtkosten für die CT- und MRT-gesteuerten Interventionen wurden als Summe aus den Gerätenutzungskosten (Anschaffungs- und Abschreibungskosten sowie Wartungskosten und Energiekosten), den Personalkosten basierend auf der Personalbindungszeit und den Kosten für das verwendete Verbrauchsmaterial ermittelt. Zusätzlich wurden die Kosten einer sonografischen Therapiesteuerung evaluiert.

Ergebnisse: Die durchschnittliche Interventionszeit betrug 24,9 Minuten (Min. 17, Max. 36 Minuten) für eine MRT-gesteuerte und 19,7 Minuten (Min 5, Max 54 Minuten) für eine CTgesteuerte Infiltration. Die durchschnittlichen Gesamtkosten je Patient beliefen sich auf EUR 240 für eine MRT-gesteuerte und EUR 124 für eine CT-gesteuerte Therapie. Dies waren (MRT-/ CT-gesteuert) EUR 150/60 je Intervention für die Gerätenutzung, EUR 46/40 für Personalkosten und EUR 44/25 für Verbrauchsmaterialien. Die Ultraschallsteuerung wies Gesamtkosten in Höhe von EUR 76 auf.

Schlussfolgerung: Zervikale Nervenwurzelinfiltrationen unter MRT-Steuerung sind aktuell noch etwa doppelt so teuer wie Interventionen unter

\section{Abstract \\ $\nabla$}

Purpose: To evaluate and compare the costs of MRI-guided and CT-guided cervical nerve root infiltration for the minimally invasive treatment of radicular neck pain.

Materials and Methods: Between September 2009 and April 2012, 22 patients (9 men, 13 women; mean age: 48.2 years) underwent MRI-guided (1.0 Tesla, Panorama HFO, Philips) single-site periradicular cervical nerve root infiltration with $40 \mathrm{mg}$ triamcinolone acetonide. A further 64 patients (34 men, 30 women; mean age: 50.3 years) were treated under CT fluoroscopic guidance (Somatom Definition 64, Siemens). The mean overall costs were calculated as the sum of the prorated costs of equipment use (purchase, depreciation, maintenance, and energy costs), personnel costs and expenditure for disposables that were identified for MRI- and CT-guided procedures. Additionally, the cost of ultrasound guidance was calculated.

Results: The mean intervention time was 24.9 min. (range: 12 - 36 min.) for MRI-guided infiltration and $19.7 \mathrm{~min}$. (range: 5-54 min.) for CTguided infiltration. The average total costs per patient were EUR 240 for MRI-guided interventions and EUR 124 for CT-guided interventions. These were (MRI/CT guidance) EUR 150/60 for equipment use, EUR 46/40 for personnel, and EUR 44/ 25 for disposables. The mean overall cost of ultrasound guidance was EUR 76.

Conclusion: Cervical nerve root infiltration using MRI guidance is still about twice as expensive as infiltration using CT guidance. However, since it does not involve radiation exposure for patients and personnel, MRI-guided nerve root infiltration may become a promising alternative to the CTguided procedure, especially since a further price decrease is expected for MRI devices and MRcompatible disposables. In contrast, ultrasound remains the less expensive method for nerve root infiltration guidance. 
CT-Steuerung. Eine fehlende Strahlenexposition der Patienten und zukünftig zu erwartende Preissenkungen für MRT-Systeme und MRT-taugliche Verbrauchsmaterialien machen MRT-gesteuerte periradikuläre Injektionstherapien jedoch zu einer vielversprechenden Alternative zur bisher üblichen CT-fluoroskopischen Steuerung. Das kostengünstige Verfahren bleibt jedoch eine Therapiesteuerung mittels Ultraschall.

\section{Introduction}

$\nabla$

Cervical pain syndrome and radicular cervical spine pain are common clinical pictures and result in significant costs for health insurance companies and the economy $[1,2]$. In patients for whom conservative treatment with physiotherapy and/or oral pain medication does not yield a satisfactory reduction in pain, minimally invasive nerve root infiltration with corticosteroids and anesthetics has proven successful as a further treatment option [3 -7]. Although rare, severe complications, such as cervical spinal marrow infarct and vertebral artery dissections, have been reported in cervical spine interventions [8-12]. Therefore, guidance via fluoroscopy or computed tomography (CT) fluoroscopy has been used to increase treatment safety $[13,14]$. Both methods have a high bone-soft tissue contrast and with almost realtime image availability they allow quick and safe anatomically exact placement of the injection cannula while protecting adjacent sensitive structures. However, it is disadvantageous that both methods use radiation and can have a potentially harmful effect both on patients and personnel [15-18]. In addition, the administration of contrast agent to check for proper distribution of the subsequently administered therapeutic agent along the nerve root is associated with a low risk for allergoid reactions [19]. Treatment guidance via MRI initially for the lumbar spine and later also for the cervical spine was able to be established in recent years as an alternative to fluoroscopic methods and ultrasound guidance [20 - 23]. The use of open MRI systems does not expose patients and personnel to radiation, provides comfortable access for the interventionalist, and receives a high degree of acceptance from patients $[24,25]$. Despite these advantages, the use of MRI for treatment guidance has not yet been able to become widely established which may be due on the one hand to the still minimal availability of open MRI systems as well as to the bias that the use of MRI necessarily entails higher costs due to the higher equipment costs, longer intervention times, and expensive MRI-compatible disposables [26].

However, a considerable reduction in the price of MRI-compatible injection cannulas has been seen in recent years. Moreover, since the development of fast MRI sequences have contributed to a shortening of the scan and intervention times and an improvement of the workflow, a significant reduction in total costs can be anticipated. From the viewpoint of providers of medical services, it is necessary to obtain robust data regarding incurred costs not only due to the introduction of the flat-rate payment system (DRG, diagnosis-related groups) as this makes it possible to select the most cost-effective method among competing methods with largely identical medical effectiveness [27-31]. The goal of this study was therefore to evaluate and compare the total costs for MRI-guided, CT-guided, and ultrasound-guided cervical nerve root infiltration from the standpoint of the radiological department.

\section{Citation Format:}

- Maurer MH, Froeling V, Röttgen R etal. MRI-Guided and CTGuided Cervical Nerve Root Infiltration Therapy: A Cost Comparison. Fortschr Röntgenstr 2014; 186: 559-566

\section{Materials and Methods}

$\nabla$

\section{Patients}

In a period from September 2009 to May 2012, 22 patients (9 men, 13 women, mean age: $48.2 \pm 10.1$ years, range: $32-77$ years) underwent cervical nerve root infiltration under therapy guidance via an open 1.0-Tesla MRI system (Panorama HFO, Philips, Best, The Netherlands). In the same period, 64 additional patients ( 34 men, 30 women; average age: $50.3 \pm 10.0$ years, range: 21 - 81 years) were treated via nerve root infiltration under CTfluoroscopic guidance (Somatom Definition 64, Siemens, Erlangen, Germany). Preinterventional MRI imaging of the cervical spine showing a compression syndrome of a cervical nerve root was available for all patients. The patients had been referred to our clinic by a treating orthopedist or neurosurgeon due to correlating pain symptoms. Written informed consent was obtained from each patient following clarification of the treatment, possible complications, and alternative treatment methods. The MRIguided periradicular infiltration treatment method was approved by the local ethics commission.

\section{Nerve root infiltration therapy techniques}

MRI-fluoroscopic nerve root infiltration

Each patient was positioned in a side position on the MRI table with the side to be treated facing up. A multifunction surface coil was positioned over the target region of the patient orthogonal to main magnetic field B0 in order to achieve the highest possible MRI signal. An interactive PDw fast spin echo (FSE) sequence (TE/TR 10/600) almost in real time was used to anatomically locate the nerve root to be treated and to guide the injection needle. $2 \mathrm{ml}$ of Xylonest $1 \%$ (Lidocaine and $1 \%$ adrenaline, AstraZeneca, Wedel, Germany) were applied subcutaneously for local anesthesia. After a point-shaped stab incision was made with a scalpel, an MRI-compatible 20G injection cannula (MReye ${ }^{\circledR}$, Cook Medical, Limerick, Ireland) was inserted dorsolaterally through the soft tissue of the neck under MRI guidance until the tip was able to be positioned directly lateral to the border of the nerve root to be treated ( $\bullet$ Fig. 1 ). After a positioning check and a position correction as necessary, a mixture of $1 \mathrm{ml}$ of triamcinolone acetonide $\left(40 \mathrm{mg}, \operatorname{Triam}^{\circledR}\right.$, Winthrop Arzneimittel $\mathrm{GmbH}$, Mühlheim, Germany) und $2 \mathrm{ml}$ of Carbostesin ( $0.5 \%$ bupivacaine hydrochloride, AstraZeneca, Wedel, Germany) was applied periradicularly. Proper distribution of the injectate was ensured with the help of a strong T2w fat-saturated FSE (SPIR, spectral presaturation with inversion recovery) sequence in axial slice orientation. An infiltration was considered technically successful in the case of proper distribution of the injectate in the periradicular space. After removal of the injection cannula, the puncture site was covered with adhesive tape. The patients were observed after the intervention for a period of 30 minutes. In the case of a lack of symptoms of aggravated pain or illness, the patients were discharged. 

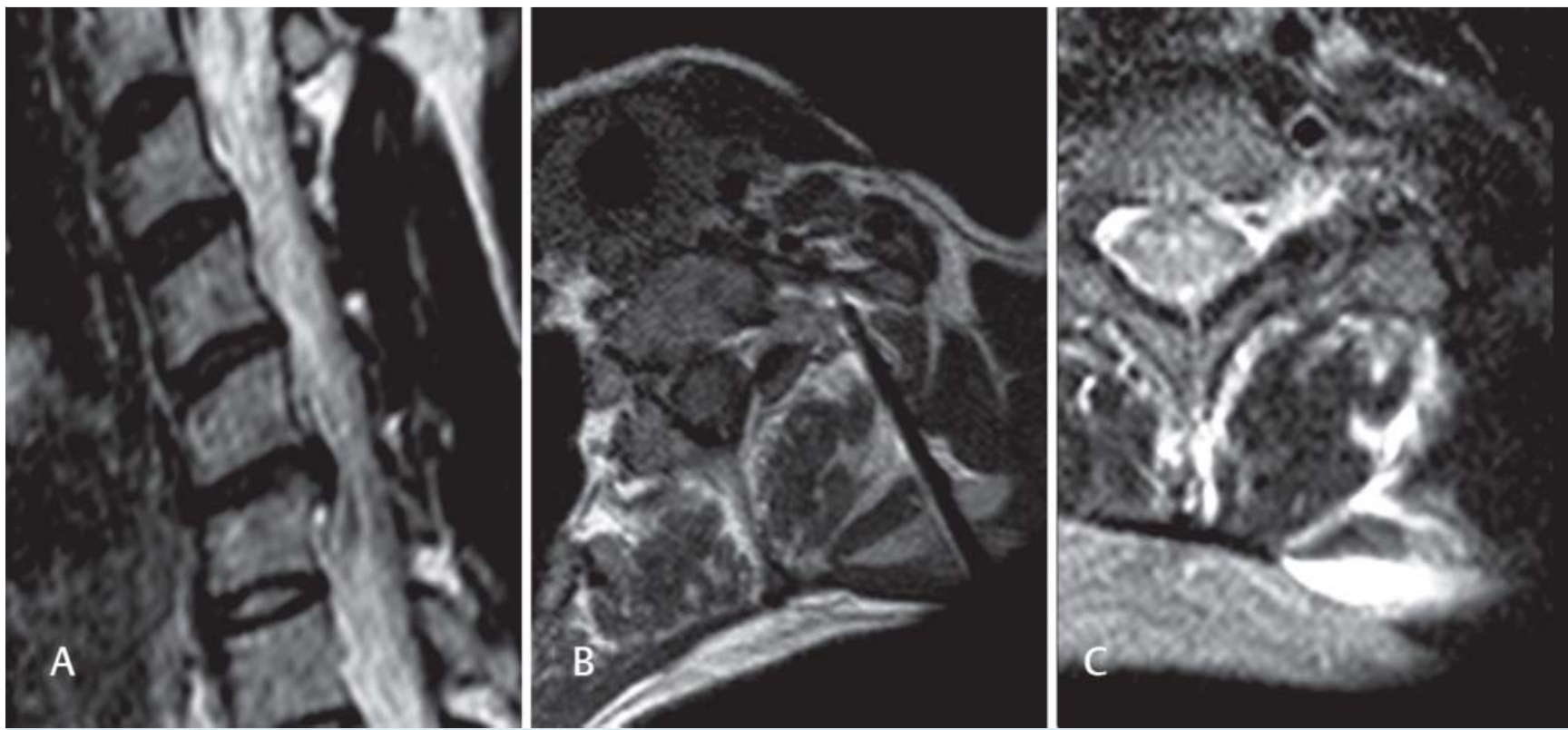

Fig. 1 Example of an MRI-guided cervical periradicular nerve root infiltration: Disc herniation C 5/6 with compression of the left C6 nerve root $\mathbf{A}$; axial PDw FSE sequence (TE/TR 10/600) with final position of the needle tip adjacent to the left C6 nerve root B; a strongly T2W FSE SPIR sequence confirms the correct application and distribution of the cortico-analgesic injection fluid $\mathbf{C}$.
Abb. 1 Beispiel einer MRT-gesteuerten periradikulären Schmerztherapie an der Halswirbelsäule: Bandscheibenprotrusion HWK 5/6 mit Bedrängung der linken C6-Wurzel A; axiale PDw-FSE-Sequenz (TE/TR 10/600) mit finaler Nadelpositionierung extraforaminal nahe der linken C6-Wurzel B; eine stark T2w-FSE-SPIR-Sequenz bestätigt die korrekte Verteilung des Injektats bestehend aus einem Kortisonpräparat und einem Lokalanästhetikum C.
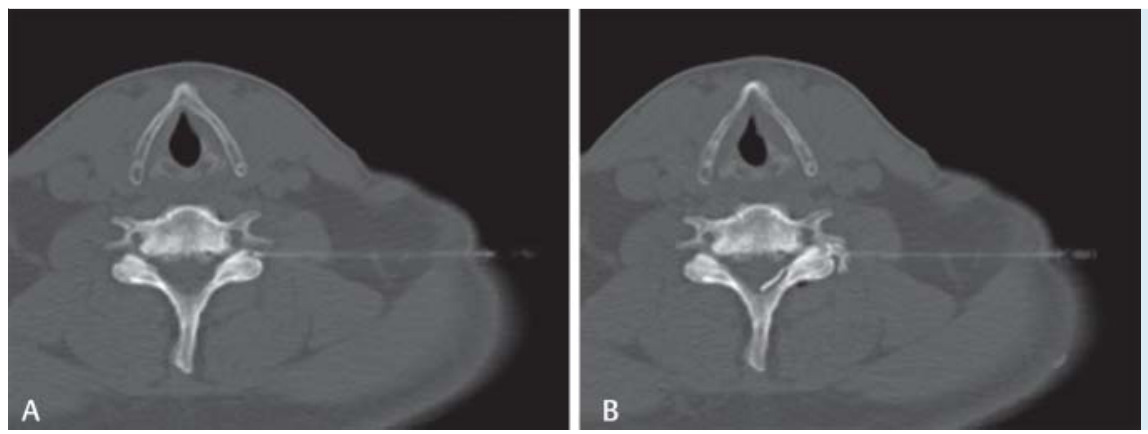

Fig. 2 Example of a CT-guided periradicular cervical nerve root infiltration: Axial CT fluoroscopic images with needle tip located close to the left cervical nerve root $\mathbf{C 6} \mathbf{A}$; after the injection the contrast medium distributes along the nerve root $\mathbf{B}$.

Abb.2 Beispiel einer CT-gesteuerten zervikalen Nervenwurzelinfiltration: Das CT-Fluoroskopie-Bild zeigt die Spitze der Injektionskanüle nahe der zervikalen linken C6-Nervenwurzel A; nach der Injektion einer geringen Menge Kontrastmittel verteilt sich dieses entlang der Nervenwurzel B.

\section{CT-fluoroscopic nerve root infiltration}

Patients were positioned in a supine position on the CT table with the head in the direction of the gantry. A lateral overview image of the cervical spine was first acquired for treatment planning. Single CT scans (or a short spiral scan in individual patients) were then acquired under consideration of the CT scout to determine the correct height of the nerve root to be treated on the $\mathrm{z}$-axis. A metal wire on the skin of the side to be treated provided orientation for determining the puncture position on the $\mathrm{xy}$ plane. The presumably correct injection site was marked on the skin with a felt-tip marker. After sterile covering and disinfection of the skin, local anesthesia was administered in the region of the planned puncture site (Xylonest 1\%, AstraZeneca, Wedel, Germany). A 22-guage injection cannula (Becton Dickinson SA, S. Agustin del Gualdix, Spain, length $90 \mathrm{~mm}$ ) was inserted under CTfluoroscopic guidance using the "step and shoot" technique and its tip was advanced to the corresponding cervical nerve root directly in front of the respective facet while protecting the vertebral artery ( $\bullet$ Fig. 2). After removal of the interior trocar, a mixture of $2 \mathrm{ml}$ of Carbostesin ( $0.5 \%$ bupivacaine hydrochloride, Astra Ze- neca, Wedel, Germany) and $1 \mathrm{ml}$ of iodine-containing contrast agent (Accupaqe 240, GE Healthcare, Munich, Germany) and $1 \mathrm{ml}$ of iodine-containing contrast agent (Accupaqe 240, GE Healthcare, Munich, Germany) was administered. The contrast agent was used to ensure proper distribution along the nerve root with homogeneous distribution in the periradicular space being considered a technically successful infiltration. $1 \mathrm{ml}$ of triamcinolone acetonide $\left(40 \mathrm{mg}\right.$, Triam ${ }^{\circledR}$, Winthrop Arzneimittel $\mathrm{GmbH}$, Mühlheim, Germany) was then administered. The effective dose applied during therapy guidance (in millisievert, $\mathrm{mSv}$ ) was approximated on the basis of the dose-length product (DLP) using the software CT-expo version 2.0.

\section{Definition and calculation of costs $\nabla$}

To calculate the total costs of the MRI-guided and CT-guided pain treatments, three different cost types including equipment usage costs, personnel costs, and material costs were used. The equipment usage costs included the costs for procurement, deprecia- 
tion, and maintenance assuming a use time of 7 years with linear depreciation according to German tax law. To calculate the equipment usage costs per intervention for the open MRI system and the CT unit, the average usage duration of the particular modality was calculated as a proportion of the annual total usage duration under consideration of the maintenance costs and the energy costs per minute of use. The costs for disposables (e.g., drapes, MRI-compatible injection cannulas, $\bullet$ Table 1 ) were provided by the hospital's purchasing department. To calculate the personnel costs for physicians and X-ray assistants, process models including all individual steps were created for both treatment methods ( 0 Table 2) [27]. The personnel needed to perform the intervention and their involvement time in minutes were allocated to each individual step. The average intervention duration could be retrospectively determined from the DICOM header of the MRI or CT image series and included the first image of the scout and the last image from CT fluoroscopy or the T2w FSE SPIR sequence. The time required for activities before and after the intervention could be determined prospectively as an average value on the basis of 5 MRI-guided and 5 CT-guided interventions. The costs for personnel minutes were then calculated on the basis of the particular involvement times of physicians and X-ray assistants under consideration of their average monthly salaries according to the civil service wage agreements minus absences due to vacation, illness, and training. The total costs were the sum of the equipment usage costs, the personnel costs, and the costs for disposables. In addition to the costs for CT and MRI guidance, the costs for sonographic treatment guidance were calculated as an additional guidance option for periradicular treatments. Additional costs types, such as room use and cleaning costs and construction costs, that could not be reliably allocated to individual interventions in our treated patient collective were not taken into consideration for the sake of simplification.

\section{Results}

All MRI fluoroscopy and CT fluoroscopy-guided interventions were able to be performed with technical success. $\$$ Fig. 3 provides an overview of the number of treatments at the different cervical nerve root locations for both procedures. The average intervention time for MRI fluoroscopy interventions was $24.9 \pm 6.3$ minutes (range: 17 - 36 minutes). Preinterventional patient preparation took an average of 22 minutes, while postinterventional activities took an average of 9 minutes. A CT fluoroscopy intervention took an average of $19.7 \pm 7.9$ minutes (range: 5 - 54 minutes) with an average of 20 minutes of preinterventional preparation and 9 minutes of postinterventional activities.

The approximated average effective dose for CT-guided interventions was $0.48 \pm 0.51 \mathrm{mSv}$ (range: $0.07-1.92 \mathrm{mSv}$ ). A short CT spiral was necessary in 17 of 64 patients for better localization of the nerve root and planning of the access. The approximated average effective dose of $0.85 \pm 0.48 \mathrm{mSv}$ (range: $0.34-1.93 \mathrm{mSv}$ ) in this patient group was significantly higher than in the subgroup without such a planning scan ( $\mathrm{t}$-test, $\mathrm{p}<0.001$ ). With an average time of 20.7 minutes, the intervention duration was not significantly higher than in the patient group without a necessary planning scan.

According to the wage contracts for physicians and civil service employees at German university hospitals, the personnel costs per minute were EUR 0.77 for the treating radiologist and EUR 0.35 for the X-ray assistant. Under consideration of the involvement times for physicians and X-ray assistants in both intervention types, the personnel costs were EUR 46.04 for an MRI-guided intervention and EUR 39.64 for a CT-guided intervention ( $\bullet$ Table 2). Costs of EUR 43.74 for MRI guidance and EUR 24.83 for CT guidance or sonographic guidance were calculated for disposables ( $\bullet$ Table 1 ). The equipment usage costs were EUR 149.65 per patient for each MRI-guided intervention and

Table 1 Costs of disposables used in CT-guided and MRI-guided cervical nerve root infiltration. The cost of disposables for ultrasound guidance was the same as for CT fluoroscopic guidance.

Tab. 1 Kosten für das Verbrauchsmaterial bei MRT- und CT-gesteuerten cervikalen Nervenwurzelinfiltrationen. Die Materialkosten bei sonografischer Steuerung entsprachen denjenigen der CT-fluoroskopischen Steuerung.

\begin{tabular}{|c|c|c|c|c|c|}
\hline type of material & manufacturer & $\begin{array}{l}\text { price } \\
\text { (in EUR) }\end{array}$ & type of material & manufacturer & $\begin{array}{l}\text { price } \\
\text { (in EUR) }\end{array}$ \\
\hline $\begin{array}{l}\text { 20G MRI-compatible puncture } \\
\text { needle, } 90 \mathrm{~mm}\end{array}$ & $\begin{array}{l}\text { Needle Chiba MReye }{ }^{\circledR} \text { Access, } \\
\text { Cook Medical, Limerick, } \\
\text { Ireland }\end{array}$ & 25.60 & $\begin{array}{l}22 \mathrm{G} \text { puncture cannula, } \\
90 \mathrm{~mm}\end{array}$ & $\begin{array}{l}\text { Becton Dickinson SA, S. Agustin del } \\
\text { Gualdix, Spain }\end{array}$ & 3.13 \\
\hline $\begin{array}{l}40 \text { mg triamcinolone aceto- } \\
\text { nide }\left(\text { Triam }^{\circledR}\right)\end{array}$ & $\begin{array}{l}\text { Winthrop Arzneimittel GmbH, } \\
\text { Mühlheim, Germany }\end{array}$ & 3.04 & $\begin{array}{l}\text { extension } \\
40 \text { mg triamcinolone aceto- } \\
\text { nide }\left(\text { Triam }^{\circledR}\right)\end{array}$ & $\begin{array}{l}\text { B. Braun, Melsungen, Germany } \\
\text { Winthrop Arzneimittel GmbH, } \\
\text { Mühlheim, Germany }\end{array}$ & $\begin{array}{l}0.74 \\
3.04\end{array}$ \\
\hline $\begin{array}{l}\text { Carbostesin }{ }^{\circledR} 0.5 \% \\
\text { (bupivacaine hydrochloride) }\end{array}$ & AstraZeneca, Wedel, Germany & 1.40 & $\begin{array}{l}\text { Carbostesin }{ }^{\circledR} 0.5 \% \\
\text { (bupivacaine hydrochloride) }\end{array}$ & AstraZeneca, Wedel, Germany & 1.40 \\
\hline $\begin{array}{l}\text { Local anesthetic } \\
\text { Xylonest }^{\circledR} 1 \% \\
\text { (Lidocaine }+1 \% \text { adrenaline) }\end{array}$ & AstraZeneca, Wedel, Germany & 1.56 & $\begin{array}{l}\text { Contrast agent Accupaque }{ }^{\circledR} \\
240 \text { (Iohexol), } 20 \mathrm{ml}\end{array}$ & GE Healthcare, Munich, Germany & 4.50 \\
\hline basic set for punctures & $\begin{array}{l}\text { MSP-Schmeisser GmbH, Horb/ } \\
\text { Neckar, Germany }\end{array}$ & 7.88 & $\begin{array}{l}\text { local anesthetic } \\
\text { Xylonest }^{\circledR} 1 \% \\
\text { (Lidocaine }+1 \% \text { adrenaline) }\end{array}$ & AstraZeneca, Wedel, Germany & 1.56 \\
\hline sterile surgical drape with hole & $\begin{array}{l}\text { Lohmann\&Rauscher Interna- } \\
\text { tional, Rengsdorf, Germany }\end{array}$ & 1.10 & basic set for punctures & $\begin{array}{l}\text { MSP-Schmeisser GmbH, Horb/ } \\
\text { Neckar, Germany }\end{array}$ & 7.88 \\
\hline sterile drape $50 \times 60 \mathrm{~cm}$ & $\begin{array}{l}\text { Lohmann\&Rauscher Interna- } \\
\text { tional, Rengsdorf, Germany }\end{array}$ & 1.68 & $\begin{array}{l}\text { Sterile surgical drape with } \\
\text { hole }\end{array}$ & $\begin{array}{l}\text { Lohmann\&Rauscher International, } \\
\text { Rengsdorf, Germany }\end{array}$ & 1.10 \\
\hline sterile gloves & $\begin{array}{l}\text { Ansell GmbH, Munich, } \\
\text { Germany }\end{array}$ & 1.48 & Sterile gloves & Ansell GmbH, Munich, Germany & 1.48 \\
\hline \multicolumn{2}{|c|}{ total cost of disposables for MRI-guided intervention (in EUR) } & 43.74 & total cost of disposables for $C$ & -guided intervention (in EUR) & 24.83 \\
\hline
\end{tabular}


Table 2 Process steps and personnel costs of CT-guided and MRI-guided nerve root infiltration.

Tab. 2 Prozessschritte und Personalkosten der CT- und MRT-gesteuerten Nervenwurzelinfiltrationstherapien.

\begin{tabular}{|c|c|c|c|c|c|c|c|}
\hline CT-guided intervention & & & & MRI-guided intervention & & & \\
\hline activity & code & minutes & total & activity & code & minutes & total \\
\hline & (costs per minute) & & & & (costs per minute) & & \\
\hline preparation & & & & preparation & & & \\
\hline patient registration & technician (0.35) & 3 & 1.05 & patient registration & technician (0.35) & 3 & 1.05 \\
\hline informational discussion & physician (0.77) & 5 & 3.85 & informational discussion & physician (0.77) & 5 & 3.85 \\
\hline $\begin{array}{l}\text { preparation of materials and } \\
\text { equipment }\end{array}$ & technician (0.35) & 5 & 1.75 & $\begin{array}{l}\text { preparation of materials and } \\
\text { equipment }\end{array}$ & technician (0.35) & 5 & 1.75 \\
\hline positioning of the patient & technician (0.35) & 3 & 1.05 & $\begin{array}{l}\text { positioning of the patient and } \\
\text { placement of the coil }\end{array}$ & technician (0.35) & 5 & 1.65 \\
\hline sterile drape & physician (0.77) & 2 & 1.54 & sterile drape & physician (0.77) & 2 & 1.54 \\
\hline preparation of injectate & physician $(0.77)$ & 2 & 1.54 & preparation of injectate & physician (0.77) & 2 & 1.54 \\
\hline & technician (0.35) & 2 & 0.7 & & technician (0.35) & 2 & 0.7 \\
\hline intervention & & & & intervention & & & \\
\hline ct scout, localization imaging & physician (0.77) & 19.7 & 15.17 & mri scout, setting of the interac- & physician $(0.77)$ & 24.9 & 19.17 \\
\hline $\begin{array}{l}\text { (single scans or short ct spiral), } \\
\text { local anesthesia, ct-guided } \\
\text { advancement of the injection } \\
\text { cannula, administration of the } \\
\text { injectate, control imaging of } \\
\text { contrast agent distribution }\end{array}$ & technician (0.35) & 19.7 & 6.90 & $\begin{array}{l}\text { tive sequence }{ }^{1} \text {, localization of the } \\
\text { target region, local anesthesia, } \\
\text { mri-guided advancement of the } \\
\text { injection cannula, administration } \\
\text { of the injectate, postinterven- } \\
\text { tional imaging }\end{array}$ & technician (0.35) & 24.9 & 8.72 \\
\hline postinterventional activities & & & & postinterventional activities & & & \\
\hline helping the patient up & technician (0.35) & 2 & 0.7 & helping the patient up & technician (0.35) & 2 & 0.7 \\
\hline final discussion & physician (0.77) & 2 & 1.54 & final discussion & physician (0.77) & 2 & 1.54 \\
\hline reporting & physician (0.77) & 5 & 3.85 & reporting & physician (0.77) & 5 & 3.85 \\
\hline $\begin{array}{l}\text { total personnel costs for } \mathrm{CT} \text {-guid- } \\
\text { ed periradicular pain therapy }\end{array}$ & & & 39.64 & $\begin{array}{l}\text { total personnel costs for MRI- } \\
\text { guided periradicular pain therapy }\end{array}$ & & & 46.06 \\
\hline
\end{tabular}

${ }^{1}$ Optional diagnostic MRI examination of the cervical spine. For ultrasound-guided interventions, a mean intervention time of 20 minutes was assumed. The pre- and post-intervention time requirement was the same as for CT-guided interventions: 15 minutes for the technician and 16 minutes for the radiologist. Overall, the mean personnel costs were 39.97 EUR per ultrasound-guided intervention.

Table 3 Costs of equipment use per intervention assuming 7-year depreciation.

Tab.3 Gerätenutzungskosten je Intervention unter der Annahme einer 7-jährigen Nutzungsdauer der verwendeten Geräte.

\begin{tabular}{|c|c|c|c|}
\hline $\begin{array}{l}\text { cost type of equip- } \\
\text { ment costs } \\
\text { (in EUR) }\end{array}$ & $\begin{array}{l}\text { CT } \\
\text { Siemens } \\
\text { Definition } 64\end{array}$ & $\begin{array}{l}\text { open MRI } \\
\text { system Philips } \\
\text { 1.0T Panorama } \\
\text { HFO }\end{array}$ & $\begin{array}{l}\text { ultrasound unit } \\
\text { Acuson Antares } \\
\text { S2000, Siemens } \\
\text { Healthcare }\end{array}$ \\
\hline purchasing costs & 670000 & $1250000^{1}$ & 129000 \\
\hline $\begin{array}{l}\text { annual mainte- } \\
\text { nance costs }\end{array}$ & 45000 & $60000^{1}$ & 4000 \\
\hline $\begin{array}{l}\text { annual usage dura- } \\
\text { tion (in minutes) }\end{array}$ & 90000 & $24000^{1}$ & 72000 \\
\hline $\begin{array}{l}\text { energy costs per } \\
\text { minute of usage } \\
\text { (in EUR) }\end{array}$ & 0.20 & 0.34 & 0.03 \\
\hline $\begin{array}{l}\text { costs per minute } \\
\text { (in EUR) }\end{array}$ & 1.56 & $3.31^{1}$ & 0.31 \\
\hline $\begin{array}{l}\text { average duration of } \\
\text { an intervention } \\
\text { (in minutes) }\end{array}$ & 34 & $41^{1}$ & $34^{2}$ \\
\hline $\begin{array}{l}\text { total equipment } \\
\text { usage costs per in- } \\
\text { tervention (in EUR) }\end{array}$ & 59.84 & $149.65^{1}$ & 11.56 \\
\hline \multicolumn{4}{|c|}{$\begin{array}{l}1 \text { Used by different departments with use by the radiological department accounting } \\
\text { for only about one third of total use; maintenance costs were taken into account } \\
\text { proportionately. The lengths of time given are procedure room usage times (roun- } \\
\text { ded to the minute). } \\
2 \text { The mean intervention time for an ultrasound-guided intervention was subject to an } \\
\text { estimate. }\end{array}$} \\
\hline
\end{tabular}

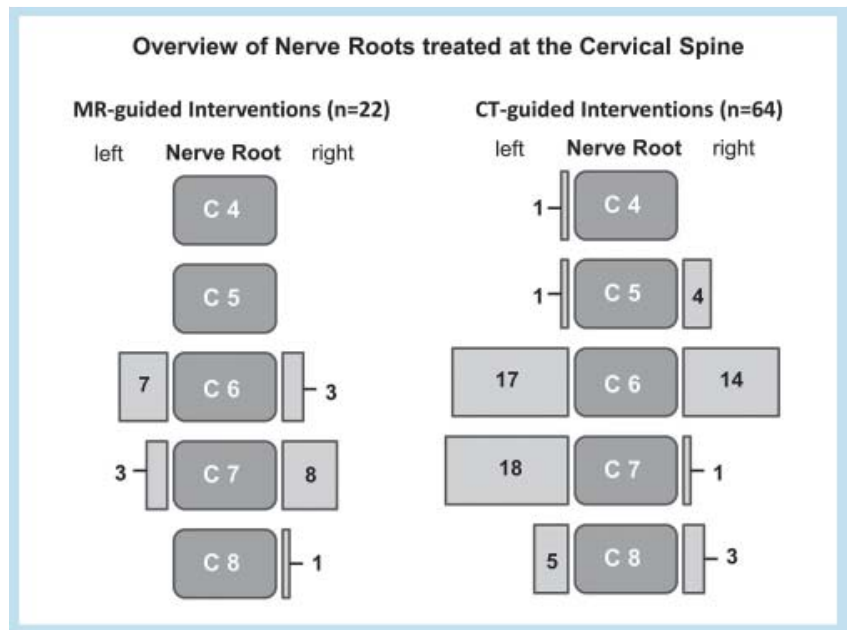

Fig. 3 Distribution of cervical spinal segments treated using MRI and CT guidance in both patient groups.

Abb. 3 Verteilung der mittels CT- und MRT-gesteuerter Infiltrationstherapie behandelten zervikalen Nervenwurzeln in den einbezogenen Patientenkollektiven. 
Table 4 Mean total costs (in EUR) per patient for CT-guided and MRI-guided nerve root infiltration.

Tab. 4 Durchschnittliche Gesamtkosten (in EUR) je Patient für eine CT- oder MRT-gesteuerte periradikuläre Schmerztherapie an der Halswirbelsäule.

\begin{tabular}{|lccl}
$\begin{array}{l}\text { Cost type } \\
\text { (in EUR) }\end{array}$ & $\begin{array}{l}\text { CT-guided } \\
\text { intervention }\end{array}$ & $\begin{array}{l}\text { MRI-guided } \\
\text { intervention }\end{array}$ & $\begin{array}{l}\text { sonographically } \\
\text { controlled } \\
\text { intervention }\end{array}$ \\
\hline $\begin{array}{l}\text { total equipment } \\
\text { usage costs } \\
\text { (incl. energy costs) }\end{array}$ & 59,84 & 149.65 & $11.56^{1}$ \\
\hline personnel costs & 39.64 & 46.06 & $39.97^{1}$ \\
\hline material costs & 24.83 & 43.74 & 24.83 \\
\hline total costs per patient & 124.31 & 239.45 & 76.36
\end{tabular}

Concerning equipment costs and personnel costs, the sonographic guidance data are estimates. The material costs for the sonographically controlled intervention corresponded to those of the CT-guided intervention.

EUR 59.84 per patient when using CT guidance ( $\bullet$ Table 3 ). The average total cost per patient was EUR 239.45 for an MRI fluoroscopy-guided nerve root infiltration and EUR 124.31 for a CT fluoroscopy-guided nerve root infiltration ( $\bullet$ Table 4). The sonographic treatment guidance method included in addition to MRI fluoroscopy and CT fluoroscopy guidance had a total cost of EUR 76.36, including an equipment usage cost of EUR 11.56, personnel costs of EUR 39.97, and material costs as in CT guidance of EUR 24.83.

\section{Discussion}

Periradicular nerve root infiltration under fluoroscopic, CT fluoroscopic, and sonographic guidance has proven to be a safe and effective therapy method for treating patients in whom conservative treatment of cervical discomfort and cervical radicular pain syndrome is not sufficient [4, $32-34]$. Therapy guidance via MRI was also able to be subsequently clinically established [22, 35]. In our study, the technical success rate was $100 \%$. Treatment with periradicular injectate distribution was able to be properly performed in all patients in both groups.

However, a cost comparison showed that the costs for MRI-guided treatment (EUR 240) were on average 1.92 times higher than the costs for CT guidance (EUR 124). The substantially higher equipment usage costs for the MRI scanner (EUR 150 vs. 60, factor 2.50) due to the substantially higher purchasing and maintenance costs for the open 1.0-Tesla MRI system contributed significantly to this. There is potential to further reduce the fixed costs per intervention, e. g. by increasing the number of treatments or by sharing equipment usage with other departments, such as the orthopedic department in our hospital and with research groups. Alanen et al. [26] compared the costs for bone biopsies under CT guidance and MRI guidance using a 0.23-Tesla low-field MRI system. The authors calculated only 1.82 times higher average equipment usage costs for MRI-guided interventions compared to CT guidance. Low-field MRI systems could also be used for MRI-guided cervical nerve root infiltration and could significantly lower the proportionate equipment usage costs [36, 37]. Compared to the use of CT and MRI for treatment guidance, the very low equipment usage costs for ultrasound units (EUR 12, factor 0.19 compared to CT equipment usage costs and factor 0.08 compared to MRI equipment usage costs) contribute greatly to the fact that ultrasound is by far the most cost-effective method.
The average costs per patient for disposables under MRI guidance were 1.76 times higher than the same costs under CT guidance in our study. Alanen et al. [26] found significantly greater differences in a cost comparison of CT-guided and MRI-guided bone biopsies with 5.57 times higher costs for MRI-compatible disposables. Primarily the cost of MRI-compatible injection cannulas is currently still several times higher (EUR 25 vs. 3, factor 8.2, - Table 1) than that of conventional cannulas that can be used for CT guidance. Although significant price reductions for MRIcompatible injection cannulas due to declining production costs and an increase in demand and production have been seen in recent years (cost per cannula in 2004 was approx. EUR 100), further potential for price reductions and greater comparability in the price of CT and MRI-compatible injection cannulas should be able to be expected given the increasing demand.

A further reason for the higher average total costs of MRI-guided interventions was the higher personnel costs (MRI/CT guidance EUR 44 vs. 25, factor 1.8). The cost difference was due to the slightly longer average intervention time for MRI-guided interventions (MRI 24.9 minutes vs. CT 19.7 minutes). To date the literature only contains intervention times for CT and MRI-guided nerve root infiltration therapies for the lumbar spine. Therefore, Sequeiros et al. [21] documented an average process time of 33 minutes (range: 9 - 84 minutes) for MRI-guided interventions, Ojala et al. [35] recorded a time of 32 minutes (range: 12-62 minutes), Fritz et al. [22] documented an average time of $42 \mathrm{~min}$ utes (range: 23 - 75 minutes) and Streitparth et al. [20] recorded a time of 27 minutes (range: 19 - 67 minutes). The average intervention time for MRI-guided cervical infiltrations of 24.9 minutes was less than the times in these studies. This is surprising in that a tendency toward a longer intervention time for the cervical spine can be assumed since the access for this intervention is often more difficult under consideration of the cervical risk structures [38]. Finally the duration of the intervention also depends on the experience of the interventionalist [20]. Therefore, the average intervention duration for the first five patients in a patient collective of Ojala et al. [35] was 34 minutes, while the average time for the last five patients was only 23 minutes. Two radiologists with MRI-guided intervention experience performed the infiltrations in our study. A learning curve was seen with an average intervention duration of 28.2 minutes for the first five patients and 19.2 minutes for the last five patients.

In addition to the examined costs, the lack of radiation exposure is an advantage of MRI-guided therapy guidance and sonographic guidance. The radiation exposure needed for CT fluoroscopic guidance has a potentially damaging effect on patients and personnel [15-17] and is of importance because many patients often require multiple interventions to achieve lasting pain relief. Hoang et al. [39] and Schmid et al. [40] documented the average effective dose in CT-guided nerve root infiltrations with the help of a phantom model and calculated average effective dose values of $0.45 \mathrm{mSv}$ and between $0.22-0.45 \mathrm{mSv}$. A similar average dose value of $0.48 \mathrm{mSv}$ (approximated) was achieved in our study. However, the increase in effective dose caused by the need for a spiral CT scan for better localization of the cervical nerve root and planning of the access was lower for the cervical spine than for the lumbar spine. Although such a scan was necessary in 17 of 64 cases in our study and the average effective dose of $0.85 \mathrm{mSv}$ was significantly higher, the increase in the study of Hoang et al. [39] was up to $2.9 \mathrm{mSv}$ for the lumbar spine. Since MRI-guided nerve root infiltration does not require radiation exposure for patients and personnel, it should be used primarily in patients with 
expected severe degenerative changes of the cervical spine, in the case of an anticipated serial therapy regimen, and in younger patients. In addition to multiplanar navigation options, MRI fluoroscopy allows precise and reliable positioning of the injection cannula and, due to the excellent soft tissue contrast, does not require iodine-containing contrast agents with a potential allergoid effect. Sonographic treatment guidance has become established as an alternative method that also does not require radiation exposure or contrast agents. Like MRI compared to CT fluoroscopy, this allows significantly better soft tissue contrast and precise visualization of sensitive structures like the vertebral artery and is primarily suitable for injections in the lower cervical spine segments $[41,42]$. Exact guidance and localization of the injection cannula increases the safety for the patient. Although rare, complications such as dissection of the vertebral artery, irreversible nerve damage and spinal, cerebellar, or cerebral infarctions have been described in connection with periradicular cervical injections $[11,43]$. The interactive PDw FSE sequence that we used allowed guidance and localization of the needle tip with precision comparable to that of CT fluoroscopy [20,44].

With respect to possible complications, the use of crystalloid and non-crystalloid corticosteroids has been controversial even though there is apparently no major difference in medical effectiveness [45]. It was assumed that complications are based on an embolic mechanism in the case of accidental injection, e.g. into a radicular artery, and corticosteroids with a clumping tendency could have a less favorable risk profile in this context [46]. Tiso et al. [47] therefore recommended using non-crystalloid corticosteroids for pain therapy in the cervical spine. However, in a large patient collective of 4612 patients treated within a period of 13 years, Schellhas et al. were not able to identify an increased incidence of complications when using crystalloid corticosteroids [32].

A limitation of our study is that the cost evaluation was limited to cost types that could be directly allocated to individual interventions from the viewpoint of a radiological department. There are certainly numerous additional costs, e.g. construction costs, cleaning costs, and data storage costs. Since these cost types could not be definitively allocated to a real patient collective, they were not included. However, energy costs that could be calculated and directly allocated to an intervention were taken into consideration. Moreover, the alternative method of fluoroscopic therapy guidance was not taken into consideration in our cost analysis. The discussion regarding costs is a current topic particularly with respect to the changes in reimbursement by statutory health insurance funds of 4/1/2013 [48]. Moreover, radiological service providers are increasingly required to bring their own services strictly in line with economic criteria and achievable revenues. System utilization optimization and revenue per time unit are important in this regard. MRI fluoroscopy-guided pain therapy at institutions with little experience in this area may initially have an unfavorable time-revenue ratio. However, a high learning curve and significant reduction in the time requirement can soon be expected.

\section{Conclusion}

\section{$\nabla$}

Cervical nerve root infiltration under MRI guidance is currently approximately twice as expensive per patient compared to infiltration therapy under CT fluoroscopy guidance. In the case of expected additional price reductions for MRI-compatible injection cannulas and possible usage of low-field scanners or conventional tunnel systems, MRI-guided nerve root infiltration seems to be a promising alternative to previously established CT fluoroscopic methods under consideration of the lack of radiation exposure for patients and personnel. However, ultrasound-guided therapy continues to be the most cost-effective method.

\section{References}

1 Martin BI, Turner JA, Mirza SK et al. Trends in health care expenditures, utilization, and health status among US adults with spine problems, 1997-2006. Spine 2009; 34: 2077-2084

2 Radhakrishnan K, Litchy WJ, O'Fallon WM et al. Epidemiology of cervical radiculopathy. A population-based study from Rochester, Minnesota, 1976 through 1990. Brain : a journal of neurology 1994; 117: $325-$ 335

3 Bush K, Hillier S. Outcome of cervical radiculopathy treated with periradicular/epidural corticosteroid injections: a prospective study with independent clinical review. European spine journal: official publication of the European Spine Society, the European Spinal Deformity Society, and the European Section of the Cervical Spine Research Society 1996; 5: 319-325

4 Wagner AL. CT fluoroscopic-guided cervical nerve root blocks. AJNR Am J Neuroradiol 2005; 26: $43-44$

5 Strobel K, Pfirrmann CW, Schmid M et al. Cervical nerve root blocks: indications and role of MR imaging. Radiology 2004; 233: 87-92

6 Vallee JN, Feydy A, Carlier RY et al. Chronic cervical radiculopathy: lateral-approach periradicular corticosteroid injection. Radiology 2001; 218: $886-892$

7 Kolstad F, Leivseth G, Nygaard OP. Transforaminal steroid injections in the treatment of cervical radiculopathy. A prospective outcome study. Acta neurochirurgica 2005; 147: 1065-1070

8 Furman MB, Giovanniello MT, O'Brien EM. Incidence of intravascular penetration in transforaminal cervical epidural steroid injections. Spine 2003; 28: $21-25$

9 Houten JK, Errico TJ. Paraplegia after lumbosacral nerve root block: report of three cases. Spine J 2002; 2: 70 - 75

10 Rozin $L$, Rozin $R$, Koehler SA et al. Death during transforaminal epidural steroid nerve root block (C7) due to perforation of the left vertebral artery. The American journal of forensic medicine and pathology 2003; 24: $351-355$

11 McMillan MR, Crumpton C. Cortical blindness and neurologic injury complicating cervical transforaminal injection for cervical radiculopathy. Anesthesiology 2003; 99: 509-511

12 Malhotra G, Abbasi A, Rhee M. Complications of transforaminal cervical epidural steroid injections. Spine 2009; 34: 731 -739

13 Rehnitz C, Wiedenhoefer B, Noeldge $G$ et al. Minimalinvasive CT-gesteuerte Wirbelsäuleninterventionen - von der Schmerztherapie über Gewebeentnahmen zur Tumortherapie. Fortschr Röntgenstr 2012; 184: 1002 - 1012

14 Meier-Meitinger M, Nagel M, Kalender W et al. Computergestütztes Navigationssystem für CT-gesteuerte Interventionen: Ergebnisse am Phantom und im klinischen Einsatz. Fortschr Röntgenstr 2008; 180: $310-317$

15 Nawfel RD, Judy PF, Silverman SG et al. Patient and personnel exposure during CT fluoroscopy-guided interventional procedures. Radiology 2000; 216: $180-184$

16 Paulson EK, Sheafor DH, Enterline DS et al. CT fluoroscopy-guided interventional procedures: techniques and radiation dose to radiologists. Radiology 2001; 220: 161 - 167

17 Hall EJ, Brenner DJ. Cancer risks from diagnostic radiology. Br J Radiol 2008; 81: $362-378$

18 Silverman SG, Tuncali K, Adams DF et al. CT fluoroscopy-guided abdominal interventions: techniques, results, and radiation exposure. Radiology 1999; 212: $673-681$

19 Pfirrmann CW, Oberholzer PA, Zanetti $M$ et al. Selective nerve root blocks for the treatment of sciatica: evaluation of injection site and effectiveness-a study with patients and cadavers. Radiology 2001; 221: $704-711$

20 Streitparth F, Walter T, Wonneberger U et al. Image-guided spinal injection procedures in open highfield MRI with vertical field orientation: feasibility and technical features. Eur Radiol 2010; 20: 395-403 
21 Sequeiros RB, Ojala RO, Klemola $R$ et al. MRI-guided periradicular nerve root infiltration therapy in low-field (0.23-T) MRI system using optical instrument tracking. Eur Radiol 2002; 12: 1331-1337

22 FritzJ, Thomas C, Clasen S et al. Freehand real-time MRI-guided lumbar spinal injection procedures at $1.5 \mathrm{~T}$ : feasibility, accuracy, and safety. Am J Roentgenol Am J Roentgenol 2009; 192: W161 -W167

23 Fritz J, Pereira PL. MR-gesteuerte Schmerztherapie: Prinzipien und klinische Applikationen. Fortschr Röntgenstr 2007; 179: 914-924

24 Bangard C, Paszek J, Berg F et al. MR imaging of claustrophobic patients in an open 1.0T scanner: motion artifacts and patient acceptability compared with closed bore magnets. Eur J Radiol 2007; 64: 152 - 157

25 Schell B, Eichler K, Mack MG et al. Roboterunterstützte Punktion in einem Hochfeld-Kernspintomografen - erste klinische Ergebnisse. Fortschr Röntgenstr 2012; 184: 42 - 47

26 Alanen J, Keski-Nisula L, Blanco-Sequeiros R et al. Cost comparison analysis of low-field ( $0.23 \mathrm{~T})$ MRI- and CT-guided bone biopsies. Eur Radiol 2004; $14: 123-128$

27 Huppertz A, Schmidt M, Wagner $M$ et al. Whole-body MR imaging versus sequential multimodal diagnostic algorithm for staging patients with rectal cancer: cost analysis. Fortschr Röntgenstr 2010; 182: $793-802$

28 Stadlbauer A, Bernt R, Salomonowitz E et al. Gesundheitsökonomische Evaluation einer Magnetresonanzbildgebung vor Biopsie zur Diagnose von Prostatakarzinomen. RoFo 2011; 183: 925-932

29 Busch HP. Imaging Center - Optimierung der diagnostischen Bildgebung im DRG-Zeitalter. Fortschr Röntgenstr 2013; 185: 313-319

30 Maurer MH, Winkler A, Wichlas F et al. Kosten und Stellenwert von Ultraschallverlaufskontrollen bei polytraumatisierten Patienten nach initialer Computertomographie. Fortschr Röntgenstr 2012; 184: 53-58

31 Hahn M, Fischbach E, Fehm T et al. Ist die Mammabiopsie ausreichend finanziert? Eine Prozesskosten \& Erlösbetrachtung. Fortschr Röntgenstr 2011; 183: 347-357

32 Schellhas KP, Pollei SR, Johnson BA et al. Selective cervical nerve root blockade: experience with a safe and reliable technique using an anterolateral approach for needle placement. AJNR Am J Neuroradiol 2007; 28: $1909-1914$

33 Galiano K, Obwegeser AA, Bodner G et al. Ultrasound-guided periradicular injections in the middle to lower cervical spine: an imaging study of a new approach. Regional anesthesia and pain medicine 2005; 30 : $391-396$

34 Narouze SN, Vydyanathan A, Kapural L et al. Ultrasound-guided cervical selective nerve root block: a fluoroscopy-controlled feasibility study. Regional anesthesia and pain medicine 2009; 34: $343-348$

35 Ojala $R$, Vahala E, Karppinen J et al. Nerve root infiltration of the first sacral root with MRI guidance. J Magn Reson Imaging 2000; 12 : $556-561$

36 Kersting-Sommerhoff $B$, Hof $N$, Lenz $M$ et al. MRI of peripheral joints with a low-field dedicated system: a reliable and cost-effective alternative to high-field units? Eur Radiol 1996; 6: 561-565
37 Hayashi N, Watanabe $Y$, Masumoto T et al. Utilization of low-field MR scanners. Magnetic resonance in medical sciences: MRMS: an official journal of Japan Society of Magnetic Resonance in Medicine 2004; 3: $27-38$

38 Bartynski WS, Whitt DS, Sheetz MA et al. Lower cervical nerve root block using CT fluoroscopy in patients with large body habitus: another benefit of the swimmer's position. AJNR Am J Neuroradiol 2007; 28: $706-708$

39 Hoang JK, Yoshizumi TT, Toncheva $G$ et al. Radiation dose exposure for lumbar spine epidural steroid injections: a comparison of conventional fluoroscopy data and CT fluoroscopy techniques. Am J Roentgenol Am J Roentgenol 2011; 197: 778-792

40 Schmid G, Schmitz A, Borchardt D et al. Effective dose of CT- and fluoroscopy-guided perineural/epidural injections of the lumbar spine: a comparative study. Cardiovasc Intervent Radiol 2006; 29: 84-91

41 Obernauer J, Galiano K, Gruber H et al. Ultrasound-guided versus Computed Tomography-controlled facet joint injections in the middle and lower cervical spine: a prospective randomized clinical trial. Medical ultrasonography 2013; 15: 10-15

42 Jee H, Lee JH, Kim J et al. Ultrasound-guided selective nerve root block versus fluoroscopy-guided transforaminal block for the treatment of radicular pain in the lower cervical spine: A randomized, blinded, controlled study. Skeletal Radiol 2013; 42: 69-78

43 Brouwers PJ, Kottink EJ, Simon MA et al. A cervical anterior spinal artery syndrome after diagnostic blockade of the right C6-nerve root. Pain 2001; 91: 397-399

44 Wonneberger $U$, Schnackenburg B, Streitparth $F$ et al. Evaluation of magnetic resonance imaging-compatible needles and interactive sequences for musculoskeletal interventions using an open high-field magnetic resonance imaging scanner. Cardiovasc Intervent Radiol 2010; 33: $346-351$

45 Lee JW, Park KW, Chung SK et al. Cervical transforaminal epidural steroid injection for the management of cervical radiculopathy: a comparative study of particulate versus non-particulate steroids. Skeletal Radiol 2009; 38: 1077-1082

46 Scanlon GC, Moeller-Bertram T, Romanowsky SM et al. Cervical transforaminal epidural steroid injections: more dangerous than we think? Spine 2007; 32: 1249-1256

47 Tiso RL, Cutler T, Catania JA et al. Adverse central nervous system sequelae after selective transforaminal block: the role of corticosteroids. Spine J 2004; 4: 468 - 474

48 Bewertungsausschuss der Kassenärztlichen Bundesvereinigung. Beschluss des Bewertungsausschusses nach $\S 87$ Abs. 1 Satz 1 SGB V in seiner 290. Sitzung (schriftliche Beschlussfassung) zur Änderung des Einheitlichen Bewertungsmaßstabes (EBM). Dtsch Arztebl 2012; 109: $51-52$ 